\title{
Reproduction Control Of Male Oreochromis Niloticus (Nile Tilapia) Using Gossypium Herbaceum (Cotton) Root Bark Meals As Fertility Inhibitor
}

\author{
B.J. Akin-Obasola, PhD \\ T. Jegede' PhD \\ Department of Forestry Wildlife and Fisheries Management, \\ Ekiti State University, Ado Ekiti, Ekiti State, Nigeria
}

doi: 10.19044/esj.2016.v12n12p218 URL:http://dx.doi.org/10.19044/esj.2016.v12n12p218

\begin{abstract}
The study was carried out to control Tilapia population using Gossypium herbaceum root bark meal (GHRBM) as reproduction inhibitor. Gossypium herbaceum (Cotton) root bark meal was fed to male O. niloticus (31.38 $\pm 0.67 \mathrm{~g})$. The root bark was added to a basal diet (35\% crude protein) at $0,5,10,15$ and $20 \mathrm{~g} / \mathrm{kg}$ diet. A total of 75 fishes were randomly distributed in triplicate into 15 plastic tanks $(1 \mathrm{x} 1 \mathrm{x} 1 \mathrm{~m}$ and 1.45 inches thick) at a stocking density of 5 fishes per $1 \mathrm{~m}^{3}$. Groundwater of 400 litres volume was maintained throughout the period of experiment. The $\mathrm{pH}$ value was between 6.90 and 7.67, temperature ranged between 25.4 and $26.6^{\circ} \mathrm{C}$ and dissolved oxygen concentration between 2.8 and $3.9 \mathrm{ml} / \mathrm{l}$. The fish was fed at 4\% body weight/day in two instalments at 09:00-09:30 hour and 17:00-17:30 hour. In fish fed $0 \mathrm{~g}$ of GHRBM/kg diet, histological examination showed spermatocytes released into the lumen of the seminiferous tubules while in fish fed $5 \mathrm{~g}, 10 \mathrm{~g}, 15 \mathrm{~g}$ and $20 \mathrm{~g}$ GHRBM/kg diets, the sections showed eroded connective tissue, hydropic degeneration, disintegration in seminiferous lobule, damaged connective tissue and increased in interstitial cells. Except in the control treatment, it was observed that $O$. niloticus spermatozoa maintained normal morphology but low sperm count and low volume. Milt volume and milt count $(\mathrm{P}<0.05)$ decreased with increase in concentration of treatments used (from 0.5 to $0.1 \mathrm{ml}$ and $3.59 \times 10^{9}$ to 0.33 $\mathrm{x} 10^{9}(\mathrm{Sperm} / \mathrm{ml})$ respectively. Weight gained was highest in fish fed $10 \mathrm{~g}$ GHRB/kg diet. It was observed that the feeding of Gossypium herbaceum root bark meals had no effect on water quality. Histological observations and milt analysis revealed that Gossypium herbaceum root bark may be effective as reproduction inhibitor in $O$. niloticus.
\end{abstract}

Keywords: Control, fertility, male, Tilapia, cotton 


\section{Introduction}

Fish protein represents a crucial nutritional component in some densely populated countries where total protein intake levels may be very low (FAO, 2014). Aquaculture, an animal food producing sector has been the fastest growing sector that has outpaced population growth (FAO, 2015). Tilapia is the second most important group of farmed fish after carp and the most widely grown of any farmed fish on the planet. It is farmed in at least 85 countries of the world (Burden, 2014). Tilapia supplied minerals and proteins in a combination offered by almost no other fish foodstuff in the world (World Ocean Review, 2012). In 2012 the FAO World Aquaculture production principal species report listed world Nile Tilapia (Oreochromis niloticus) production at $3,197,330$ metric tons valued at $\$ 5,260,695,000$ USD. Tilapias are known for their ability to sexually mature at a small size, around 8-10 $\mathrm{cm}$ in body length, and at a young age (sometimes when 2-3 months old) (Chapman, 2012). Adult fish are known to live six to eight years, while some have been reported to reach eleven to twelve years of age. In tropical regions, the spawning season of tilapia usually begins during the raining season when water temperatures begin to rise, and spawning continues throughout the year as long as water temperatures are above $22^{\circ} \mathrm{C}$ (Chapman, 2012). Tilapia is tagged “aquatic chicken” (Macleans, 1984) because it can be cultured profitably in a wide range of systems from simple backyard systems to highly intensive "factory farm" as you can in poultry. It will survive in brackish water and some will adapt to full strength sea water. These characteristics make tilapias suitable for culture in most developing countries where they are most often grown in ponds, cages, rice field, raceways, and concrete tanks (Fagbenro, 2002). Tilapias spawn and produce offspring with ease and these make them good fish to farm. However, this trait also creates problems. Survival of the young is high and grow-out ponds can become crowded, fish become stunted as the supply of natural food organisms in the pond is depleted (Fagbenro, 2002).

Mair and Little (1991) reviewed several population control methods in farmed tilapia. They reported several effective methods that have been used to control such undesirable tilapia population which includes: monosex culture, tank culture, (grading, hybridization, manual sexing), sex reversal by androgenic hormones, cage culture tank culture, the use of predators, high density stocking (stocking manipulation), sterilization (through the use of irradiation, chemosterilants and other reproduction inhibitors), intermittent/selective harvesting, the use of slow-maturing tilapia species, among others. All these population control methods however have their inadequacies and limitations. The need arises therefore to examine less expensive and appropriate technology in addressing the problem of uncontrolled breeding in tilapia using biological inhibitory agents. Therefore, 
plants, such as Gossypium herbaceum, with anti-fertility properties, may likely offer possible solution to the precocious growth and uncontrolled reproduction in tilapia.

Gossypium herbaceum, also called Levant cotton, is a species of cotton native to the semi-arid regions of sub-Saharan Africa and Arabia where it still grows in the wild as a perennial shrub. It was first cultivated in Western Sudan from there it spread to India, before being introduced to Egypt. It reached China in the $700 \mathrm{AD}$ and was first cultivated from this period (Yelena et.al. 2012). Gossypium is in the cotton genus. It belongs to the kigdom Plantae, the tribe Gossypieae, in the mallow family, Malvaceae and genus, Gossypium. The genus Gossypium comprises around 50 species making it the largest in species number in the tribe Gossypioieae. The species of this genus are extraordinarily diverse in morphology and adaptation, ranging from fire-adapted, herbaceous perennials in Australia to trees in Mexico (Kumar et. al. 2012). Cultivated cottons are perennial shrubs most often grown as annuals (Yelena et. al. 2012). The presence of saponins, tannins and alkaloids which have been used as contraceptive substances were reported in the preliminary phytochemical analysis of this plant.

\section{Materials and Methods}

Gossypium herbaceum root bark was collected from Ado- Ekiti, Ekiti State, Nigeria. It was shade dried, milled into fine particle sizes of 10 microns, packed into a dry clean polythene bag and kept inside the freezer at $4^{0} \mathrm{C}$ till it was used. Five isonitrogenous diets were formulated to provide $35 \%$ crude protein using menhaden fish meal (65\% crude protein), yellow maize, vegetable oil, vitamin-mineral premix and soy bean meal (as shown in table 1).

Table 1: Composition (g/kg) of experimental diet using milled Gossypium herbaceum root bark.

\begin{tabular}{cccccc}
\hline Ingredients & (control) & 5 & 10 & 15 & 20 \\
\hline Menhaden & 270 & 270 & 270 & 270 & 270 \\
Soya meal & 385 & 385 & 385 & 385 & 385 \\
Yellow maize & 245 & 245 & 245 & 245 & 245 \\
Cod liver oil & 30 & 30 & 30 & 30 & 30 \\
Corn oil & 20 & 20 & 20 & 20 & 20 \\
Vit-mineral premix(1:1) & 30 & 30 & 30 & 30 & 30 \\
Corn starch & 20 & 20 & 20 & 20 & 20 \\
Gossypium herbaceum root & 0 & 5 & 10 & 15 & 20 \\
bark & & & & & \\
Moisture & 1000 & 1000 & 1000 & 1000 & 1000 \\
Crude Protein & 10.71 & 11.51 & 10.81 & 10.85 & 10.75 \\
Crude lipid & 35.95 & 35.69 & 35.61 & 35.52 & 35.12 \\
Crude fibre & 13.80 & 13.86 & 13.56 & 13.81 & 13.98 \\
Ash & 6.20 & 6.80 & 7.11 & 7.81 & 8.00 \\
NFE $* *$ & 8.55 & 7.50 & 8.26 & 8.30 & 7.96 \\
& 24.79 & 24.63 & 24.65 & 23.71 & 24.19 \\
\hline
\end{tabular}


Determined using standard method (AOAC, 1995)

**NFE (Nitrogen Free Extract) $=100-($ Crude protein + Crude fibre + Crude lipid + Moisture + Ash)

The dietary ingredients were purchased at Metrovet Feed shop, AdoEkiti, Ekiti State, Nigeria. All the dietary ingredients were milled to small particle sizes of 10 microns, weighed and mixed in a Hobart A-200T pelleting and mixing machine. Hot water was added at intervals to gelatinize starch.

Fishes in control experiment were fed with $0 \%$ Gossypium herbaceum, treatment $1 ; 5 \mathrm{~g}$ GHRBM $/ \mathrm{kg}$, treatment 2; $10 \mathrm{~g} \mathrm{GHRBM} / \mathrm{kg}$, treatment 3; $15 \mathrm{~g}$ GHRBM $/ \mathrm{kg}$ and treatment 4; 20g GHRBM $/ \mathrm{kg}$. The feed was pelletized using $0.8 \mathrm{~mm}$ diameter die. They were air-dried at ambient temperature of $22^{0} \mathrm{C}$ for 72 hours on a raised concrete platform to constant moisture content. The dried diets were broken up, sieved into small pellet sizes, packed in polythene bags, labelled and stored. Juvenille male $O$. niloticus were obtained from Ekiti State Ministry of Agriculture and Natural Resources Fish Farm, Ado Ekiti. They were transported live to FAME fish farm, Ado Ekiti, inside aerated polythene bags.

The fishes were fed with coppens (30\% crude protein) for 14 days. A total of $75 \mathrm{O}$. niloticus fingerlings were purchased. After acclimation, five male O. niloticus $(30.10 \pm 0.06 \mathrm{~g})$ were stocked in each of the 15 experimental plastic tanks containing borehole water. Each treatment was replicated thrice. Feeding of fish commenced after acclimatization and it lasted for 70 days. The fishes were fed at $4 \%$ body weight/day in two instalments at 0900-0930 $\mathrm{h}$ and 1700-1730h. Fish were weighed after seventy day experimental treatment.

Milt production and quality were determined at the end of the experiment. Two male fish, randomly selected from each treatment were used. Milt was obtained by putting the fish in water containing 2phenoxyethanol (400mg/L) (SRAC, 2004) to make milt collection easier. Drummond microcaps disposable micropipettes were used to collect the milt by torching the papilla opening with the pipette. Milt volume was measured using syringe of $1.0 \mathrm{ml}$ capacity calibrated in $0.1 \mathrm{ml}$. Motility duration was determined by placing $1 \mu \mathrm{l}$ of milt from each male on a Neubauer haemocytometer, a drop of distilled water was added and covered with a slip. The sperm activity was viewed under Olympus BH2 microscope at $100 \mathrm{X}$ magnification and motility was determined by the progressive and nonprogressive movements of the sperms observed. (Mims, 1991). Milt count was determined by counting the number of spermatozoa in diluted sample $\left(10 \mu \mathrm{l}\right.$ sperm in $90 \mu \mathrm{l}$ MFR to make 100) (dilution ${ }_{1}$ ), $10 \mu$ l dilution in $90 \mu \mathrm{l}$ MFR to make 100 (Dilution 2). $0.1 \mathrm{~mm}$ of the dilute was dropped on 
Neubauer haemocytometer and sperm counted under the microscope at 400X magnification using Sharma et. al. 2011 method.

Histological examination of organs (testes and liver) was carried out at the end of the experiment. Two male fishes were taken from each tank, weighed and killed by decapitation. Both the testes and liver tissues were removed for sectioning and histological examination. The organs were fixed in formal-saline solution made of equal volumes of $10 \%$ formalin and $0.9 \%$ sodium chloride solution. The organs were removed, put in cassettes and processed in Shandon Citadel 2000 machine after which they were embedded in wax, trimmed and sectioned. Using microtone, histological sections of $5 \mu \mathrm{m}$ thickness were prepared following standard procedures (Histology Laboratory Manual 2011-2012). Sections were fixed on clean slides and stained with haematoxylin and eosin. Photomicrographs were taken with Leitz (Ortholux II) microscope and camera, standard model BHTU-111.

Boxplot was used to test for outliers for each of the reproductive parameters measured. Normality test was assessed using Shapiro-Wilk Test $(\mathrm{P}<0.05)$ respectively.

Using Analysis of Variance (ANOVA) test, milt volume, milt count, motility duration and testes weight of the different treatment levels were checked for statistical significant differences. Turkey test was used to compare differences among individual means.

Growth rate and feed conversion ratio were determined using the following formula;

$$
\text { Growth rate }=\frac{\ln W_{1} \times \ln W_{0}}{T}
$$

FCR= Dry weight of feed fed (g) / Fish weight gain (g)

\section{Results}

\section{TESTIS}

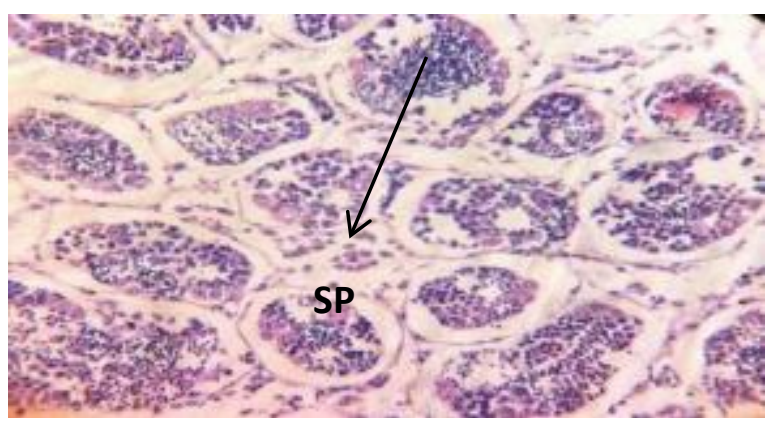

Plate 1: Section of testes in $O$. niloticus fed $0 \mathrm{~g}$ of $\mathrm{GHRB} / \mathrm{kg}$ diet showing spermatocytes

(SP) released into the lumen of the seminiferous tubule. Mag. X100. 


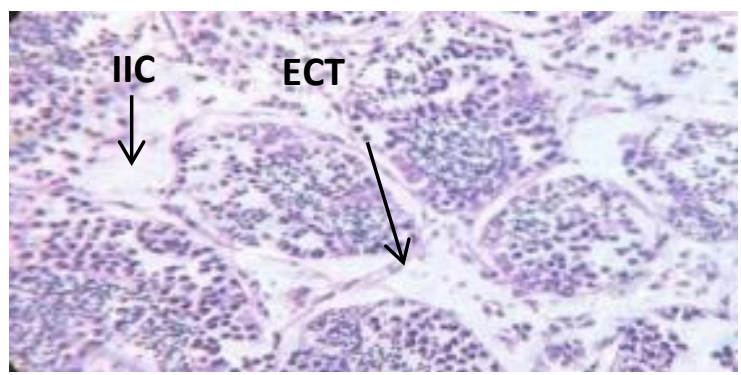

Plate 2: Section of testes in O. niloticus fed $5 \mathrm{~g}$ of GHRB/kg diet showing eroded connective tissue (ECT) and increase in interstitial cell (IIC). Mag. X100.

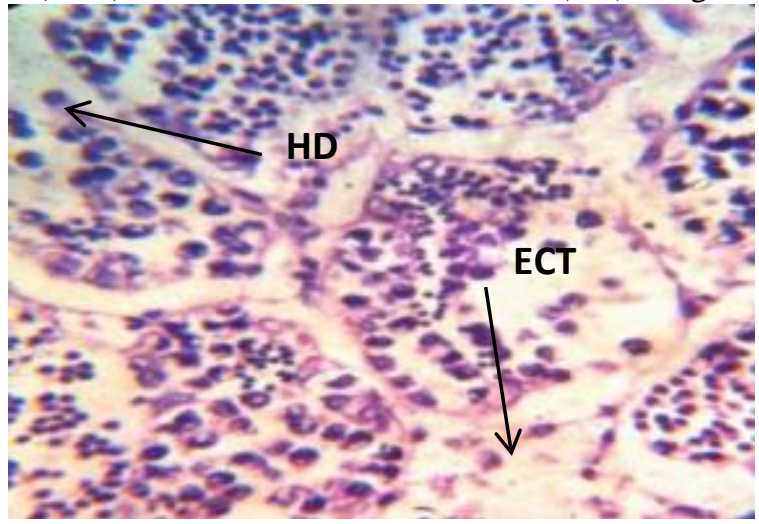

Plate 3: Section of testes in O. niloticus fed $10 \mathrm{~g}$ of GHRB/kg diet showing eroded connective tissue (ECT) and hydropic degeneration (HD). Mag. X100.

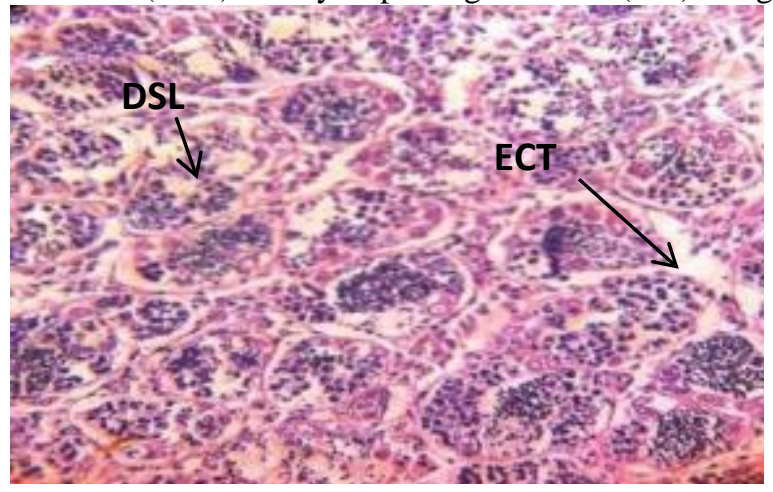

Plate 4: Section of testes in O. niloticus fed $15 \mathrm{~g}$ of GHRB/kg diet showing disintegration in seminiferous lobule (DSL) and eroded connective tissue (ECT). Mag. X100. 


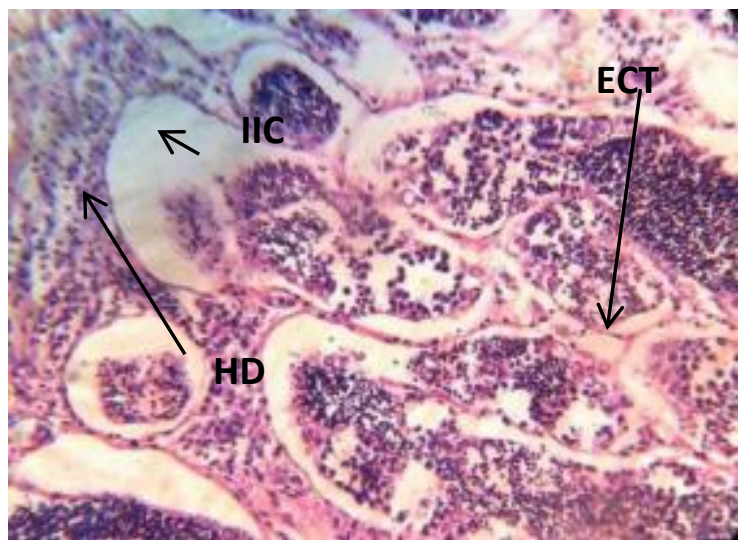

Plate 5: Section of testes in O. niloticus fed 20g of GHRB/kg diet showing hydropic degeneration (HD), increase in interstitial cells (IIC) and eroded connective tissue (ECT). Mag. X100.

Liver

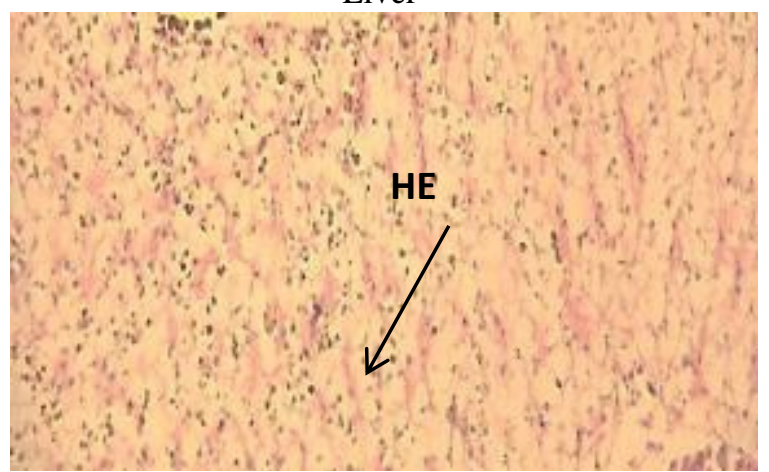

Plate 6: Section of liver in O. niloticus fed $0 \mathrm{~g}$ of GHRB/kg diet showing normal hepatocellular (HE) architecture. Mag. X100.

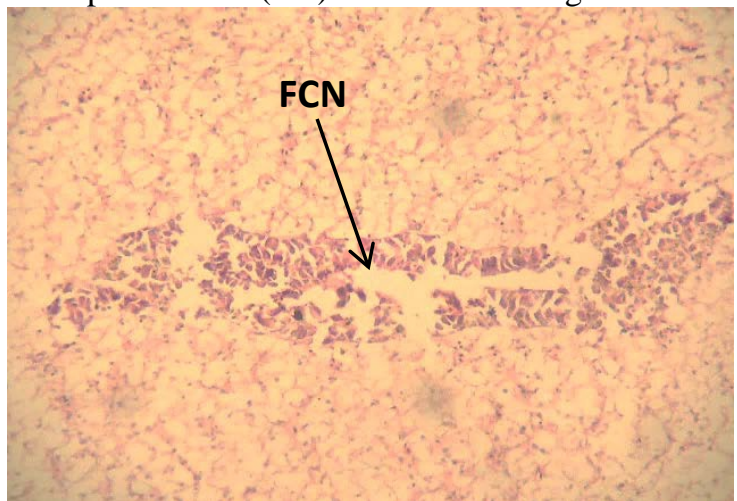

Plate 7: Section of liver in O. niloticus fed $5 \mathrm{~g}$ of GHRB/kg showing focal coagulative necrosis (FCN). Mag. X100. 


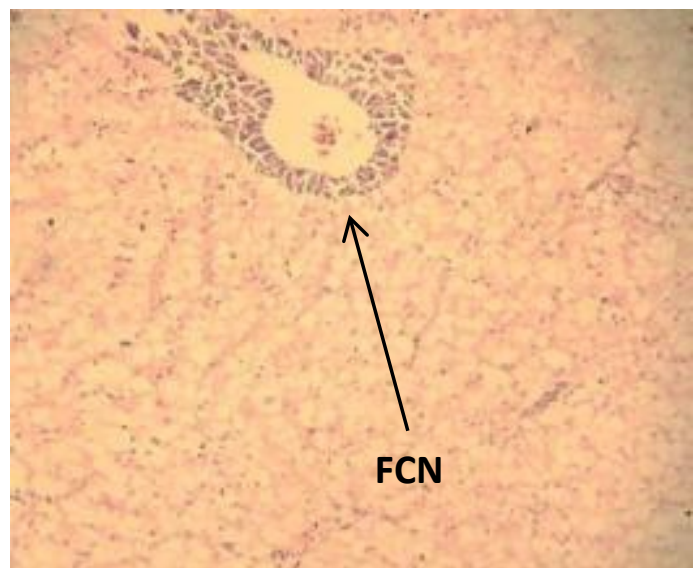

Plate 8: Section of liver in O. niloticus fed $10 \mathrm{~g}$ of GHRB/kg diet showing focal coagulative necrosis (FCN). Mag. X100.

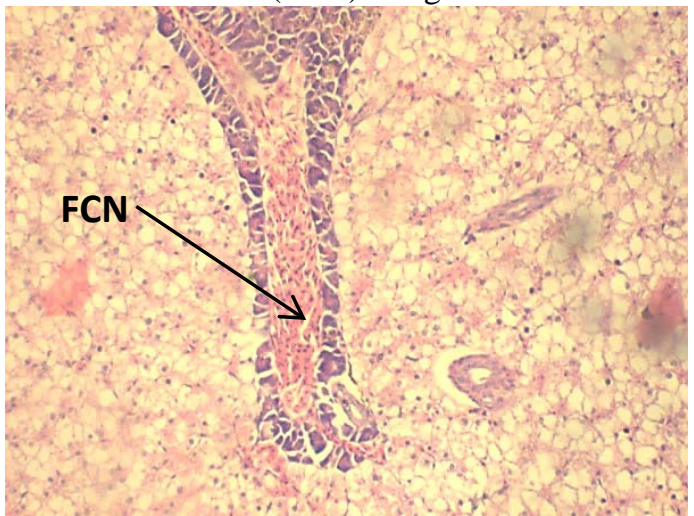

Plate 9: Section of liver in O. niloticus fed $15 \mathrm{~g}$ of GHRB $/ \mathrm{kg}$ diet showing focal coagulative necrosis (FCN). Mag. X100.

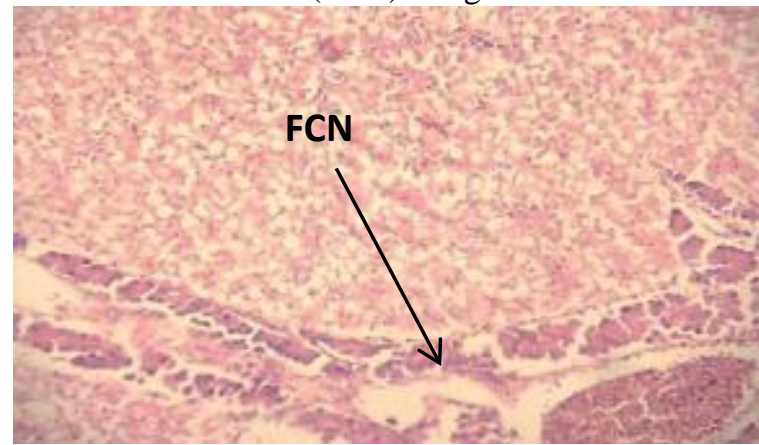

Plate 10: Section of liver in O. niloticus fed $20 \mathrm{~g}$ of GHRB/kg diet showing focal coagulative necrosis (FCN). Mag. X100.

Using boxplot, there were no outliers for each of the reproductive parameters measured. All the parameters measured were normally distributed except milt volume and milt count as assessed by Shapiro-Wilk Test $(\mathrm{P}<0.05)$ respectively. 
Table 2: Analysis of reproductive parameters of adult male Oreochromis niloticus fed Gossypium herbaceum root bark meal.

\begin{tabular}{|c|c|c|c|c|c|}
\hline \multicolumn{6}{|c|}{ Concentration (g) } \\
\hline Parameters & 0 & 5 & 10 & 15 & 20 \\
\hline Milt volume (ml) & $0.50 \pm \frac{a}{a} 0.06$ & $0.43 \pm 0.03$ & $0.47 \pm \underset{a}{ \pm 0.03}$ & $0.43 \pm 0.03^{\mathrm{a}}$ & $0.23 \pm 0.03$ \\
\hline Milt count $\times 10^{9}(\mathrm{~s} / \mathrm{ml})$ & $\underset{\mathrm{a}}{3.44 \pm 0.56}$ & $2.07 \pm 0.03$ & $\underset{\mathrm{c}}{1.74 \pm 0.02}$ & $1.77 \pm 0.03$ & $\underset{\mathrm{e}}{0.46 \pm 0.05}$ \\
\hline Testes weight (g) & $0.53 \pm 0.01^{\mathrm{a}}$ & $\underset{\mathrm{a}}{0.54 \pm 0.02}$ & $\underset{\mathrm{a}}{0.55 \pm 0.02}$ & $0.54 \pm 0.01^{\mathrm{a}}$ & $\underset{\mathrm{a}}{0.54 \pm 0.01}$ \\
\hline $\begin{array}{l}\text { Motility duration } \\
\text { (min) }\end{array}$ & $\underset{\mathrm{a}}{4.38 \pm 0.10}$ & $3.20 \pm 0.03$ & $\underset{\mathrm{c}}{2.15 \pm 0.02}$ & $1.07 \pm 0.03^{\mathrm{d}}$ & $\underset{\mathrm{e}}{0.13 \pm 0.27}$ \\
\hline
\end{tabular}

Means with the same letters are not significantly different at $5 \%$ probability.

From table 2 above, it was revealed that; milt volume was highest in control experiment but lowest in concentration 20. Milt count (measured in $\mathrm{X} 10^{9}$ (sperm/ml), reduced with increase in concentration of treatments used and motility duration reduced with increased level of treatment. 0; (4.38 \pm 0.18$), 5$; $(3.20 \pm 0.06), 10$; $(2.15 \pm 0.04), 15$; $(1.07 \pm 0.05)$ and 20; $(0.13 \pm 0.05)$. Testes weight was lowest in concentration 0 but highest in concentration 10. Statistical analysis $(\mathrm{P}<0.05)$ revealed that milt volume, milt count and motility duration of the different treatment levels were significantly different. While testes weight of the different treatment levels were not significantly different.

Table 3: Growth parameters and nutrient utilization of adult male Oreochromis niloticus fed Gossypium herbaceum root bark meal.

\begin{tabular}{|c|c|c|c|c|c|}
\hline \multicolumn{7}{|c|}{ Concentration (g) } \\
\hline Parameters & 0 & 5 & 10 & 15 & 20 \\
\hline Fish initial & $31.07 \pm 0.17^{\mathrm{a}}$ & $30.59 \pm 1.33^{\mathrm{a}}$ & $31.38 \pm 0.67^{\mathrm{a}}$ & $30.72 \pm 0.25^{\mathrm{a}}$ & $30.45 \pm 0.07^{\mathrm{a}}$ \\
weight (g) & $90.55 \pm 0.67^{\mathrm{a}}$ & $82.18 \pm 0.35^{\mathrm{b}}$ & $90.76 \pm 0.13^{\mathrm{a}}$ & $87.58 \pm 1.45^{\mathrm{a}}$ & $92.37 \pm 0.28^{\mathrm{c}}$ \\
Fish final & $99.43 \pm 0.55^{\mathrm{a}}$ & $97.89 \pm 0.42^{\mathrm{a}}$ & $100.41 \pm 2.16^{\mathrm{a}}$ & $98.32 \pm 0.81^{\mathrm{a}}$ & $97.44 \pm 0.22^{\mathrm{a}}$ \\
weight (g) & $59.47 \pm 0.59^{\mathrm{a}}$ & $51.59 \pm 0.45^{\mathrm{b}}$ & $59.38 \pm 0.63^{\mathrm{a}}$ & $56.85 \pm 1.21^{\mathrm{c}}$ & \\
Feed Fed (g) & $1.33 \pm 0.00^{\mathrm{a}}$ & $1.23 \pm 0.00^{\mathrm{b}}$ & $1.33 \pm 0.03^{\mathrm{a}}$ & $1.31 \pm 0.01^{\mathrm{a}}$ & $61.92 \pm 0.21^{\mathrm{a}}$ \\
Weight Gain & $1.67 \pm 0.02^{\mathrm{a}}$ & $1.90 \pm 0.02^{\mathrm{b}}$ & $1.69 \pm 0.06^{\mathrm{a}}$ & $1.73 \pm 0.02^{\mathrm{c}}$ & $1.39 \pm 0.00^{\mathrm{a}}$ \\
Specific & & & & & $1.57 \pm 0.00^{\mathrm{a}}$ \\
Growth Rate & & & & & \\
Feed & & & & & \\
Conversion & & & & & \\
Ratio & & & & & \\
\hline
\end{tabular}

Means with the same letters are not significantly different with SPSS at $5 \%$ probability.

From table 3 above, it was seen that weight gain was significantly different in concentrations 0,5 and 15 and while it was not significantly different in treatments 0 and 10 . Weight gain was highest in concentration 
20. Feed conversion ratio was lowest in concentration 20 at $1.57 \pm 0.00$ and similar $(\mathrm{P}>0.05)$ in concentrations $0(1.67 \pm 0.02), 10(1.69 \pm 0.06)$ and 20 (1.57 \pm 0.00$)$.

Table 4: Water quality analysis for Oreochromis niloticus fed Gossypium herbaceum root bark meal.

\begin{tabular}{|c|c|c|c|c|c|c|}
\hline \multirow[b]{2}{*}{$\begin{array}{c}\text { Concentrati } \\
\text { on }\end{array}$} & \multicolumn{3}{|c|}{ Day 1} & \multicolumn{3}{|c|}{ Day14 } \\
\hline & $\begin{array}{c}\text { Temperatu } \\
\text { re }\end{array}$ & $\mathrm{pH}$ & $\mathrm{DO}_{2}$ & $\begin{array}{c}\text { Temperatu } \\
\text { re }\end{array}$ & $\mathrm{pH}$ & $\mathrm{DO}_{2}$ \\
\hline 0 & $\underset{\mathrm{a}}{26.53 \pm 0.03}$ & $6.91 \pm 00^{\mathrm{a}}$ & $\begin{array}{c}3.30 \pm 0.30 \\
0^{\mathrm{a}}\end{array}$ & $25.50 \pm 00^{\mathrm{a}}$ & $\underset{\mathrm{a}}{7.34 \pm 0.06}$ & $\begin{array}{c}3.53 \pm 0.2 \\
7^{\mathrm{a}}\end{array}$ \\
\hline 5 & $\underset{\mathrm{a}}{26.43 \pm 0.03}$ & $6.91 \pm 00^{\mathrm{a}}$ & $3.90 \pm 00^{\mathrm{a}}$ & $\underset{\mathrm{a}}{25.53 \pm 0.07}$ & $\underset{\mathrm{a}}{7.57 \pm 0.05}$ & $\begin{array}{c}3.83 \pm 0.0 \\
7^{\mathrm{a}}\end{array}$ \\
\hline 10 & $\underset{\mathrm{a}}{26.30 \pm 0.12}$ & $\begin{array}{c}6.91 \pm 0.0 \\
1^{\mathrm{a}}\end{array}$ & $3.23 \pm 0.23^{\mathrm{a}}$ & $\underset{\mathrm{a}}{25.47 \pm 0.07}$ & $\begin{array}{c}7.56 \pm 0.02 \\
a\end{array}$ & $\begin{array}{c}3.77 \pm 0.0 \\
3^{\mathrm{a}}\end{array}$ \\
\hline 15 & $\underset{\mathrm{a}}{26.43 \pm 0.03}$ & $6.92 \pm 00^{\mathrm{a}}$ & $3.60 \pm 0.30^{\mathrm{a}}$ & $\underset{\mathrm{a}}{25.43 \pm 0.03}$ & $\underset{\mathrm{a}}{7.32 \pm 0.11}$ & $\begin{array}{c}3.87 \pm 0.0 \\
3^{\mathrm{a}}\end{array}$ \\
\hline 20 & $\underset{\mathrm{a}}{26.47 \pm 0.03}$ & $6.91 \pm 00^{\mathrm{a}}$ & $3.57 \pm 0.28^{\mathrm{a}}$ & $\underset{\mathrm{a}}{25.53 \pm 0.03}$ & $\underset{\mathrm{a}}{7.42 \pm 0.08}$ & $\begin{array}{c}3.83 \pm 0.0 \\
7^{\mathrm{a}} \\
\end{array}$ \\
\hline
\end{tabular}

Means with the same letters are not significantly different at 5\% probability.

Table 4 showed that there were no significant differences in all the parameters measured on day 1 and day 14 of the experiment.

\section{Discussion}

In male O. niloticus fed $0 \mathrm{~g}$ of GHRBM/kg diet (Plate 1), histological examination showed normal testes architecture; spermatocytes were being released into the lumen of the seminiferous tubule. This was authenticated by Morrison et. al. (2006) while in fish fed $5 g$ GHRBM/kg diet (Plate 2) the section revealed eroded connective tissue and increased in interstitial cells. In fish fed 10g, $15 \mathrm{~g}$ and $20 \mathrm{~g}$ GHRBM/kg diets (Plates 3, 4 and 5 ), the sections showed eroded connective tissue, hydropic degeneration, disintegration in seminiferous lobule, damaged connective tissue and increase in interstitial cells.

In a similar experiment, Akin-Obasola and Jegede (2013) observed that, in fish fed $40 \mathrm{~g}$ Momordica charantia leaf meal $/ \mathrm{kg}$ diet, section of the testes showed cystic tubule and highly reduced matured germinal cell in the confluence of the seminiferous tubule. Fish fed $60 \mathrm{~g}$ diet showed necrosis, very few matured germinal cell in the lumen of preceding ducts and disintegration in sperm cells while fish fed $80 \mathrm{~g}$ showed necrosis, severe atrophy, very few matured germinal cell in the lumen of preceding ducts and disintegration in sperm cells. According to Akin-Obasola and Jegede (2014), histological observations and fecundity analysis of $T$. zillii fed high dietary Momordica charantia leaf meal revealed necrosis of the gonad and low 
fecundity respectively. Severe degeneration and autolysis of seminiferous tubules was also reported by Feng, (2011) who fed $2 \mathrm{~g}$ pawpaw seed powder per kg diet to $O$. niloticus for 15 and 30 days.

In a similar anti-fertility study by Verma and Chinoy (2002), papaya seed extract was administered intramuscularly on male albino rats at $5 \mathrm{mg} . \mathrm{kg} / \mathrm{day}$ for 7 days and this resulted in severe decrease in the contractile response of epididymal tubules when compared with the control experiment.

In table 2, milt volume was higher in control and decreased $(0.50 \pm 0.06,0.43 \pm 0.03,0.47 \pm 0.03,0.43 \pm 0.03$ and $0.23 \pm 0.03)$ with increasing concentration of Gossypium herbaceum in the diet. Milt count was also higher in control and decreased (3.44 $\pm 0.56,2.07 \pm 0.03,1.74 \pm 0.02,1.77 \pm 0.03$ and $0.46 \pm 0.05$ ) as the inclusion level of Gossypium herbaceum increases. Motility also decreased $(4.38 \pm 0.10,3.20 \pm 0.03,2.15 \pm 0.02,1.07 \pm 0.03$ and $0.13 \pm 0.27)$ as the inclusion level of Gossypium herbaceum increases. Ibraheem et.al. (2007) also reported sterility in male Srague Dawley rats treated with $1 \mathrm{~g} / \mathrm{kg}$ methanolic lead extract of the root of Mangifera indica plant.

As shown in Tables 3, the best overall growth response was noticed in control experiment which was fed basal diet. Weight gained, feed efficiency ratio, specific growth rate and feed conversion ratio were optimal in control experiment and treatment $10 \mathrm{~g}$ GHRBM/kg diet. This result could be improvement in appetite which may be caused by higher inclusion of Gossypium herbaceum in treatment $10 \mathrm{~g}$ GHRBM $/ \mathrm{kg}$ diet. Gossypium herbaceum is reported by Rahman et. al. (2012) as tonic used in improving appetite in animals. Lynne et.al. (2008) also reported that in animals, castration may be intended for favouring a given desired development and this may be improvement in weight added. There were no significant variations $(\mathrm{P}<0.05)$ in growth performance of other treatments used. Weight gained was between $42.75 \pm 0.61$ and $61.92 \pm 0.21$, Feed efficiency ratio was $53-60 \%$. Ndome et. al. (2011) recommended feed efficiency ratio of 50\% and above. Feed conversion ratio was 1.5-2.0. This is an optimal result as Ofori et.al. (2009) recommended 1.4-2.5. The use of Gossypium herbaceum root bark meals as reproduction inhibitors could be the panacea to the problem of early maturation and uncontrolled reproduction of tilapia most especially in developing countries of the world which are characterized with poor and low income.

\section{References:}

Akin-Obasola, B. J. and Jegede T. (2013). Histology and semen analysis of Tilapia zillii (gervais, 1848) fed bitter melon (Mormodica charantia) leaf meal diets. International Symposium On Tilapia in Aquaculture. $6^{\text {th }}-10^{\text {th }}$ October 2013, Ramada Jerusalem, Israel. Pp 1-8. 
Akin-Obasola, B. J. and Jegede T. (2014). Histological Analysis of Female Redbelly Tilapia; Tilapia zillii (Gervais, 1848) Ovary, Fed Bitter Melon, Momordica charantia (Cucurbitaceae) Leaf Meal. Journal of Agricultural Science; (6)11: 229-237.

AOAC (Association of Official Analytical Chemists). (1995). In: Cunniff P.A. (Ed.). Official methods of analysis $16^{\text {th }}$ Edn. Arlington, V.A, Pp 1141.

Burden, D. (2014). Tilapia profile. International and special project, Extension value added agriculture and Agricultural Marketing Resource centre, Iowa State University. Pp 1-4.

Chapman, F. A. (2012). Culture of hybrid tilapia: a reference profile. Fisheries and Aquatic Sciences Department, Institute of Food and Agricultural Science (IFS) Report. University of Florida. Gainesville. Pp 1-5. Fagbenro, O. A. (2002). Tilapia: Fish for thought. Inaugural lecture series 32. The Federal University of Technology, Akure, Nigeria. 77pp.

Feng, E. (2011). Bitter gourd (Momordica charantia) is a cornucopia of health: a review of its credited antidiabetic, anti-HIV, and antitumor properties." Curriculum for Molecular Medicine. 2011 Jul; A Review Paper.11 (5):417-36.

Food and Agriculture Organization of the United Nation (2014). Food energy- Method of analysis and conversion factors. FAO Food and Nutrition. 77: 73-78.

Food and Agriculture Organisation of the United Nation (2015). The post 2015 development agenda and millennium development goals. Fisheries, aquaculture, oceans and seas. Pp 1-3.

Histology Laboratory Manual (2011-2012). College of Physicians and Surgeons, Colombia University. Available at: http://histologylab.ccnmtl.columbia.edu/HistologylabManual.pdf

Ibraheem S.O., Olatunji -Bello I. I., Awobajo, F. O. (2007). Anti-fertility effect of methanolic leaf extract of Magnifera Indica (mango leaves) on male Srague Dawley rats. Federation of American Societies for experimental Biology Journal. 21 (9); 34-40.

Jegede, T. and Fagbenro, O. A. (2007). Tilapia husbandry vs. midwifery: use of antifertility plants. Pp.118-122, in G.E. Onibi, S.O. Agele, V.A.J. Adekunle and M.O. Olufayo (eds.) Proceedings of the Third Annual Conference of School of Agriculture and Agricultural Technology, Federal University of Technology Akure, Nigeria.

Jegede, T. and Fagbenro, O. A. (2008a). Histology of gonads in O.niloticus fed pawpaw (Carica papaya) seed meal diets. $8^{\text {th }}$ International Symposium of Tilapia in Aquaculture. In: Elghobashy, H. and Fitzsimmons, K. (eds). Egypt, Cairo. Pp 1135- 1141.

Jegede, T. and Fagbenro, o. A. (2008b). Histology of gonads in Tilapia zillii (gervais) fed neem (azadirachta indica) leaf meal diets. $8^{\text {th }}$ International 
Symposium on Tilapia In quaculture. In: Elghobashy, H. and Fitzsimmons, K. (eds). Egypt, Cairo. Pp 1129-1134.

Jegede, T. (2011). Effects of Aloe vera (Liliaceae) on the Gonad development in Nile tilapia, Oreochromis niloticus (Linnaeus, 1758). $9^{\text {th }}$ International Symposium On Tilapia In aquaculture. In : Lie, L. and Fitzsimmons, K. (eds). Shanghai, China. Pp 1-10.

Jegede, T. (2010). Control of reproduction in Oreochromis niloticus (Linnaeus, 1758) using Hibiscus rosa-sinensis (Linn.) leaf meal as reproduction inhibitor. Journal of Agriculture Science. 2 (4): 149- 154.

Kumar D., A.Kumar and Prakash O. (2012). Potential antifertility agents from plants: a comprehensive review. Journal of Ethnopharmacol. 140 (1): 1-32.

Mair, G. C. and Little D. C. (1991). Population control in farmed tilapia. NAGA, ICLARM. Quarterly 14: 8-13

Morrison , C. M., Fitzsimmons, K. and Wright Jr, J. R. (2006). Atlas of tilapia histology. World Aquaculture Society, USA. Pp 96.

Ofori, J. K., Dankwa, H. R., Brummett, R. and Abban, E. K. (2009). Producing Tilapia in Small Cage in West Africa. World fish Center Technical Manual. No 1952. The World fish Center, Penang, Malaysia. Pp 16.

Sharma, P. K., Sisidia, S. S., Naruka, P.S., and Mayur, P. (2011). In-vitro antioxidant activity of Gossypium herbaceum Linn. International Research Journal of Pharmacy. 2 (7): 166-170.

Verma R. J. and Chinoy N. J. (2002). Effects of papaya seed extract on contractile response of Cauda epididymal Tubules. Asian Journal of Andrology. 4 (1): 77 - 78.

World Ocean Review (2012). Fish and Folk. In: Tim, S. and Dimitri, L. (eds). Published by Maribus gGmbH. Hamburg. Pp 40.

Yelena Yalli, PharmD, Maria Kostka-Rokosz, PharmD, Lana Dvorkin, PharmD, Julia W. (2012). Boston Healing Landscape Project; A Programme for the study of cultural, therapeutic. and religious pluralism. Boston University. Pp 1-3. 